\title{
Создание русско-тувинского параллельного подкорпуса электронного корпуса тувинского языка: первые итоги"
}

\author{
Аэлита Я. Салчак, Валентина С. Ондар \\ Тувинский государственный университет, Российская Федерация
}

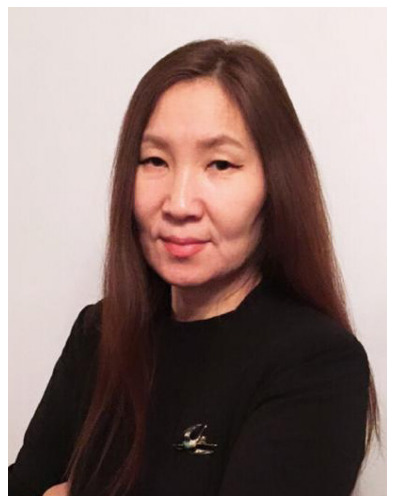

В статье представлены предварительные итоги работ по созданию русско-тувинского параллельного подкорпуса электронного корпуса тувинского языка, которые ведутся в Научно-образовательном центре «Тюркология» Тувинского государственного универcumema.

Рассмотрено примерное количество переводных русско-тувинских произведений, в том числе переводных произведений как зарубежных писателей, так и писателей национальных республик Советского Союза, переведенных на тувинский язык с русского языка. Авторами были использованы данные Национальной библиотеки Тувы и Тувинского государственного университета. По данным картотек библиотек насчитывается более 700 переводных произведений.

В состав русско-тувинского параллельного подкорпуса включены переведенные на тувинский язык произведения М. Ю. Лермонтова «Герой нашего времени», М. А. Шолохова «Поднятая целина», В. П. Катаева «Я, сын трудового народа», А. П. Чехова «Человек в футляре» А. Фадеева «Молодая гвардия» М. Горького «Свидание», Б. Васильева «А зори здесь тихие», Е. Ильиной «Четвертая высота». На 2019 г. объем собранного русско-тувинского параллельного корпуса составляет 7631813 словоупотреблений.

В работе приводятся примеры выравнивания русско-тувинских параллельных текстов, рассмотрена проблема перевода этнокультурных реалий на тувинский язык. Сравнительный анализ русско-тувинских параллельных текстов показывает степень эквивалентности и неэквивалентности перевода; трудности передачи лексики, содержащей национально-культурный компонент (слова-реалии); лексико-семантические и стилистические трансформации при переводе.

Ключевые слова: тувинский язык; русский язык; переводная литература; корпусная лингвистика; электронный корпус; электронный корпус тувинского языка; параллельный текст

" Работа выполнена в соответствии с планом научно-исследовательских работ Государственного задания Министерства образования и науки Российской Федерации № 1.4539.2017/8.9 (проект № 34.3876.2017/ПЧ).

\section{Для цитирования:}

Салчак А. Я., Ондар В. С. Создание русско-тувинского параллельного подкорпуса электронного корпуса тувинского языка: первые итоги [Электронный ресурс] // Новые исследования Тувы. 2020, № 1. URL: https://nit.tuva.asia/ nit/article/view/912 (дата обращения: дд.мм.гг.). DOI: 10.25178/nit.2020.1.6

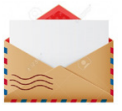

Салчак Аэлита Яковлевна - кандидат филологических наук, доцент, старший научный сотрудник Научно-образовательного центра «Тюркология» Тувинского государственного университета. Адрес: 667000, Россия, г. Кызыл, Студенческий квартал, д. 5, ауд. 129. Тел.: +7 (394-22) 2-19-69. Эл. адрес: aelita_74@mail.ru

ORCID ID: 0000-0003-2304-6901

Ондар Валентина Сувановна - кандидат филологических наук, старший преподаватель, старший научный сотрудник Научно-образовательного центра «Тюркология» Тувинского государственного университета. Адрес: 667000, Россия, г. Кызыл, Студенческий квартал, д. 5, ауд. 129. Тел.: +7 (394-22) 2-19-69. Эл. адрес: barys-hoov@mail.ru ORCID ID: 0000-0002-6882-7720

Salchak Aelita Yakovlevna, Candidate of Philology, Associate Professor, Senior researcher, Research and Education Center of Turkic Studies, Tuvan State University. Postal address: R. 129, 5 Studencheskii Kvartal, 667000 Kyzyl, Russian Federation. Tel.: +7 (394-22) 2-19-69. E-mail: aelita_74@mail.ru

Ondar Valentina Suvanovna, Candidate of Philology, Senior lecturer, Senior researcher, Research and Education Center of Turkic Studies, Tuvan State University. Postal address: Room 129, 5 Studencheskii Kvartal, 667000 Kyzyl, Russian Federation. Tel.: +7 (39422) 2-19-69. E-mail: barys-hoov@mail.ru 


\title{
Setting up a parallel Russian-Tuvan subcorpus within the electronic corpus of Tuvan language: preliminary outcomes
}

\author{
Aelita Ya. Salchak, Valentina S. Ondar \\ Tuvan State University, Russian Federation
}

\begin{abstract}
The article presents preliminary outcomes of setting up a subcorpus of parallel texts in Russia and Tuvan, which is to become part of the electronic corpus of Tuvan language. The work on the subcorpus is being carried out at the Research and Education Center for Turkic Studies at the Tuvan State University.

The subcorpus includes data from a certain number of works of literature translated from Russian into Tuvan. They were written by foreign authors or those from the ethnic republics of the Soviet Union, and then translated into Tuvan. For sources, the corpus relies on the collections of the National Library of Tuva and Tuvan State University, which together have over 700 works of literature that fall within this group.

The Russian-Tuvan parallel text subcorpus includes, among other works, M.Yu. Lermontov's “A Hero of Our Times”, M.A. Sholokhov's “Virgin Soil Upturned", V.P. Katayev's "I am the Son of the Nation of Labour", A.P. Chekhov's "Man in a Case", A.A. Fadeev's "The Young Guard", Maxim Gorky's “The Rendez Vous”, B.A. Vasilyev's “The Dawns Here Are Quiet”, Ye. Ilyina's “Fourth Height”. As of 2019, the total volume of the corpus is 7631813 word samples.

The article provides examples of alignment of Russian and Tuvan parallel texts, with a focus on how words referring to ethnospecific realities are translated into Tuvan. A comparative analysis of Russian-Tuvan parallel texts allows researchers to assess the adequacy of translation, the difficulty of translating vocabulary belonging to the ethnically and culturally specific group of "reality words", as well as the lexical, semantic and stylistical transformation as a result of translation.
\end{abstract}

Keywords: Tuvan language; Russian language; translated literature; corpus linguistics; electronic corpus; electronic corpus of Tuvan language; parallel text

"The work was performed in accordance with the research plan of the State task of the Ministry of Higher Education and Science of the Russian Federation No. 1.4539.2017/8.9 (project No. 34.3876.2017/PCH).

\section{For citation:}

Salchak A. Ya. and Ondar V. S. Setting up a parallel Russian-Tuvan subcorpus within the electronic corpus of Tuvan language: preliminary outcomes. The New Research of Tuva. 2020, no. 1 [online] Available at: https://nit.tuva.asia/nit/ article/view/912 (access date ...). DOI: 10.25178/nit.2020.1.6

\section{Введение}

На сегодняшний день невозможно представить сохранение и развитие языков без информационных технологий. В этом отношении создание и развитие электронных корпусов является одним из инструментов поддержки языков и эффективности филологических исследований. Корпусная лингвистика является интенсивно развивающейся областью лингвистики. На данный момент созданы и функционируют корпусы для многих мировых языков. Активно развивается и совершенствуется Национальный корпус русского языка (НКРЯ) http://ruscorpora.ru, объем которого составляет более 600 млн слов. Наряду с этим ведется планомерная работа по созданию корпусов для языков России. Успешно развиваются татарский национальный корпус (http://tugantel.tatar/), корпусы башкирского (http://bashcorpus.ru/), калмыцкого (kalmcorpora.ru), бурятского (http://web-corpora.net/BuryatCorpus/ search/index.php) и др. языков.

Важным шагом для начала планомерной работы по созданию электронных ресурсов для тувинского языка можно считать создание на базе Тувинского государственного университета научнообразовательного центра «Тюркология», сотрудниками которого ведется большая работа по созданию Электронного корпуса тувинского языка (ЭКТЯ). О некоторых итогах, неотложных задачах и перспективах создания электронных ресурсов тувинского языка отмечено в статье директора НОЦ «Тюркология» М. В. Бавуу-Сюрюн (Бавуу-Сюрюн, 2006). Проблемы и перспективы создания электронного корпуса текстов тувинского языка, принципы морфологической разметки, вопросы создания подкорпусов электронного корпуса текстов тувинского языка рассматривались в работах российских и зарубежных ученых (Хертек, Ооржак 2012; Салчак, Байыр-оол 2013; Tyers, Bayyr-ool, 
Salchak, Washington, 2016; Washington, Bayyrool, Salchak, Tyers, 2016; Салчак, Ондар, Кужугет, 2018). Основные результаты работы представлены на сайте ЭКТЯ http://www.tuvancorpus.ru/.

Работа над созданием тувинско-русского и русско-тувинского параллельных подкорпусов ЭКТЯ началась в феврале 2017 г. в рамках выполнения проекта Тувинского государственного университета, поддержанного грантом по проектной части Государственного задания Министерства образования и науки Российской Федерации № 1.4539.2017/8.9 (проект № 34.3876.2017/ПЧ) по теме «Системные изменения в языковой картине тувинцев России и зарубежья: традиции и современность» (руководитель Б. Ч. Ооржак). Работа ведется силами научных сотрудников НОЦ «Тюркология» и студентов Тувинского госуниверситета: М. В. Бавуу-Сюрюн, Б. Ч. Ооржак, В. С. Ондар, А. Я. Салчак, А. Б. Хертек, А. А. НараМандып, Б. О. Нара-Мандып, Б. А. Бавуу-Сюрюн. Основными задачами проекта является анализ системных изменений в языковой картине мира тувинцев России и зарубежья. Системные изменения в грамматике и лексике наблюдались, в том числе, и в параллельных русско-тувинских и тувинскорусских текстах. Поэтому была начата работа по созданию русско-тувинского и тувинско-русского параллельных подкорпусов ЭКТЯ. В работе над созданием русско-тувинского параллельного подкорпуса принимают участие научные сотрудники НОЦ «Тюркология» - авторы данной статьи.

Как известно, параллельный корпус - это двуязычный корпус, содержащий текст на языке оригинала и его перевод. Данные параллельных корпусов могут быть полезны при проведении сопоставительных исследований, исследований, касающихся теории перевода, межкультурной коммуникации, что подтверждается результатами работ, проведенными на базе параллельных корпусов НКРЯ (Добровольский, Кретов, Шаров, 2005; Андреева, 2006; Добровольский, 2009). В параллельном корпусе НКРЯ представлены 19 языков, из языков России имеются на сегодняшний день башкирский и бурятский параллельный корпусы.

Цель статьи - представление первых итогов работы по созданию русско-тувинского параллельного корпуса. Проанализированы исследования по анализу русско-тувинской переводной литературы, по языковому анализу параллельных текстов на материале тюркских языков Южной Сибири.

\section{Русско-тувинская переводная литература}

Существует большой массив параллельных русско-тувинских текстов. Это в основном художественная литература, тексты официально-деловых документов и др. Художественные произведения, переведенные с русского на тувинский язык, имеются в Национальной библиотеке им. А. С. Пушкина Республики Тыва, в архиве Тувинского института гуманитарных и прикладных социально-экономических исследований, в научно-библиографическом отделе с сектором краеведения и редких изданий Тувинского государственного университета.

При подготовке статьи авторами были использованы данные двух библиотек: Национальной библиотеки им. А.С. Пушкина Республики Тыва, научно-библиографического отдела с сектором краеведения и редких изданий Тувинского государственного университета. В их картотеках насчитывается более 700 переводных произведений.

В числе переводных произведений имеются тексты переводов как зарубежных писателей, так и писателей национальных республик Советского Союза, переведенных на тувинский язык с русского языка. Например, А. К. Дойл «Приключения Шерлока Холмса» (А. Денберел), Д. Дефо «Робинзон Крузо» (М. Момбужай), Джек Лондон «Белый клык» (Х.М. Саая), «Любовь к жизни» (М. Б. Сагды), У. Шекспир «Ромео и Джульетта» (С. Пюрбю), Братья Гримм «Белая змея» (А. К. Калзан), Э. Распэ «Приключения барона Мюнхаузена» (А. Делгер-оол), С. Экзюпери «Маленький принц» (А. А. Даржай), М. Проспер «Маттео фальконе» (Л. Кан-оол), В. Гюго «Гаврош» (С. Сарыг-оол), Г. Х. Андерсен «Кому-то передающая речь» (Б. Монгуш), «Сказки Андерсена» (М. Байыр-оол), Ю. Фучик «Слово перед казнью» (Д. Монгуш), Васамурти «Удивительное путешествие озорника» (К. Ч. Донгак), Р. Гонсалес «Взгляд матери» (С. Сереноол), Г. Олесь «Черный яр» (М. Хомушку), Н. Думбадзе «Я, бабушка, Илико и Илларион» (С. Миндрия), «Златокудрая девочка. Армянские сказки» (Т. Донгак), С. Айни «Школа» (Д. Кысыгбай), А. Абдулла «Болтливая утка» (К. Доржку), Р. Сейсенбаев «Окончилась суббота» (А. Даржай), М. Магауин «Наш родственник, дядя моих детей» (Ч. Доржу), А. Шынбатыров «Айсауле» (В. Монгуш), М. Карим «Радость нашего дома» (М. Доржу), Ч. Айтматов «Первый учитель» (Б. Л. Ондар), «Судьба Саралы» (В. Б. Монгуш), М. О. Ауэзов «Серый Лютый (В. Монгуш), Ю. Рытхэу «Благодатное слово» (О. Дарыма), «Эвенкийские сказки» (О. Дарыма), М. Ефимов «Чуткий и меткий» (А. Даржаа), Ц. Дамдинжапов «Мать» (Б. Хөвеңмей), В. Митыпов «Норжима» (Д. Монгуш), Ц.-Д. Хамаев «Сестра» (Э. Кечил-оол), «Сборник стихов и рассказов 
бурятских писателей на тувинском языке» (С. Тамба, Ю. Кюнзегеш, Х. Ойдан-оол, С. Сүрүң-оол, М. Доржу, К. Кудажы, В. Серен-оол, Ч. Серен-оол, Э. Кечил-оол, М. Кенин-Лопсан, В. Монгуш, С. Куулар), К. Телесов «Цветы мигают» (В. Серен-оол), Л. Кильчичаков «Сказка о хитрой лисе» (Ю. Кюнзегеш), Н. Г. Доможапов «В далеком аале» (В. Монгуш, Я. Хертек), Л. Ч. Дамба «Прозрачный Тамир» (К. Д. Аракчаа), Тудэв Л. «За полярной звездой» (Б. Х. Болдур-оол, К.Т. Аракчаа), Удвал С. «Свет» (Г. Б. Санчаа).

Переводная русская литература на тувинском языке, особенности первых переводных произведений тувинской литературы, анализ художественных переводов с русского на тувинский язык были произведены в работах А. К. Калзана, Д. С. Куулара (Калзан, Куулар, 1956), У. А. Донгак (Донгак, 2018) Как отмечает У. А. Донгак, «собственно перевод с русского языка появляется, судя по сохранившимся изданиям, с книжки малого формата в 18 страниц «Учитель Ленин» («Paşkь Lenin», 1931, 5 тысяч
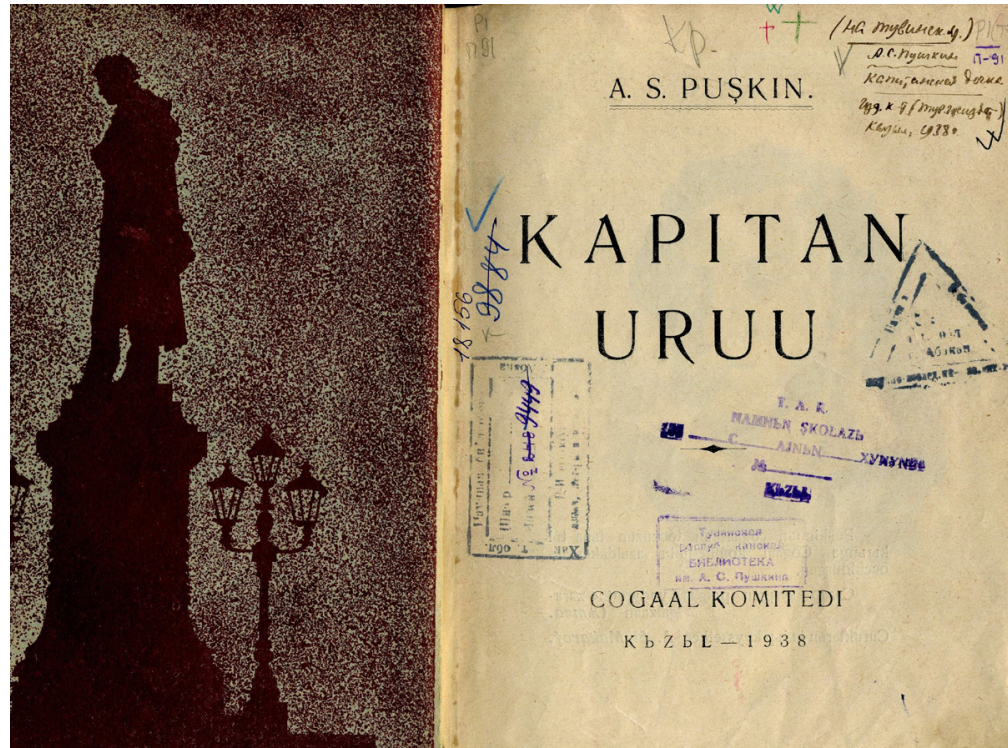
экземпляров)» (Донгак, 2018: 30).

Первые художественные произведения, переведенные с русского на тувинский язык, появились в 1937 г. В это время были переведены некоторые стихотворения А. С. Пушкина. Первое прозаическое произведение, переведенное на тувинский язык в 1938 г. роман А.С. Пушкина «Капитанская дочка». Сказка в стихах П. П. Ершова «Конек-Горбунок» была переведена также в 1938 г.

В 1940-е годы переведены на тувинский язык и изданы произведения М. Горького «Макар Чудра» (С. Сарыгоол), «Сказка об Иване-царевиче и сером волке» (И. Монгуш), «Девушка и смерть» (И. Монгуш), «Детство» (С. Серен), «В Америке» (А. Делгероол), У. Шекспира «Ромео и Джульетта» (С. Пюрбю), В. В. Бианки «Хитрый заяц» (С. Пюрбю), Братьев Гримм «Каша в кувшине» (С. Пюрбю), В. В. Маяковского «Что такое хорошо и что такое плохо» (И. Монгуш), А. С. Пушкина «Сказка о попе и о его работнике Балде» (И. Монгуш), М. Ю. Лермонтова «Герой нашего времени» (О. Саганоол), Д. Н. Мамина-Сибиряка «Емеляохотник», «Медвежонок» (И. Монгуш), В. Л. Василевской «Радуга» (М. ХенчеКара, А. Дембирел, К. Сат, М. Хомушку); Н. В. Гоголя «Тарас Бульба» (Ю. Кюнзегеш), «Ревизор» (Ш. Сат); Е. Ильиной «Четвертая высота» (К. Кудажы), Е. Кощевой «Повесть о сыне» (С. Сарыг-оол).

В 1950-е годы на тувинский язык

Фото 1-2. Первое прозачческое произведение, переведенное на тувинский язык латиницей в 1938 г., - роман А. С. Пушкина «Капитанская дочка».

Титул и первый разворот издания. Фото предоставлено сотрудниками сектора книжных памятников Национальной библиотеки им А. С. Пушкина.

Photo 1. The first prose work translated into the Tuvan language (making use

of Latin alphabet) in 1938 was the novel "The Captain's Daughter" by A. S. Pushkin. Photo courtesy of the Book Monuments Sector, A.S. Pushkin National Library of Tuva.

переведены произведения М. Ю.Лермонтова «Герой нашего времени» (О. К. Саган-оол), Е. Кошевой «Повесть о сыне» (С. Сарыг-оол), В.П. Катаева «Сын полка» (С. Сюрюн-оол), Б. Полевого «Мы - советские люди» (С. Сюрюноол), Н. В. Гоголя «Тарас Бульба» (Ю. Кюнзегеш), М. Горького «Мать» (С. Сарыг-оол), В.П. Катаева «Я, сын трудового народа» (С. Сарыг-оол), 


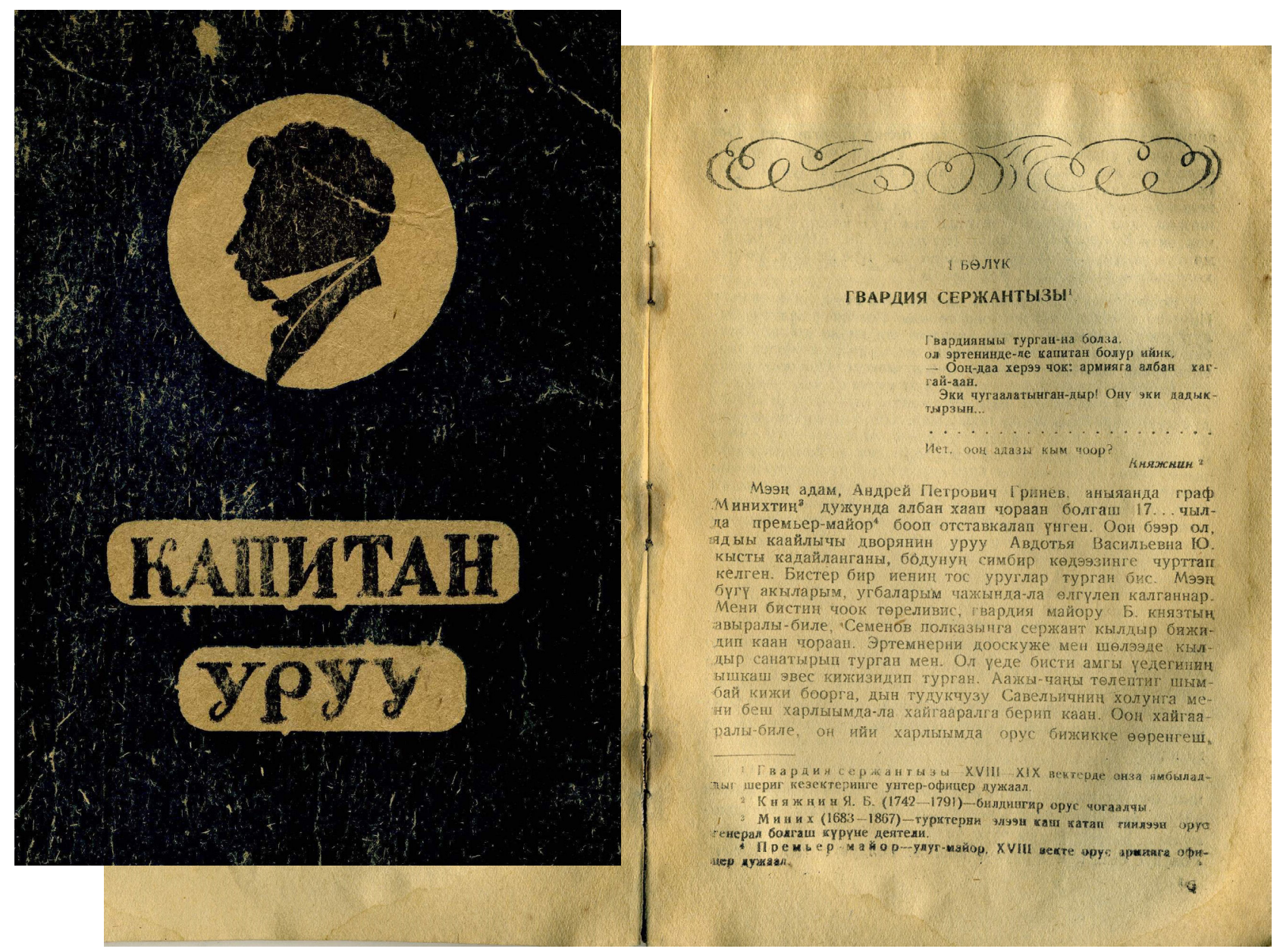

Фото 3-4. Прозаическое произведение, переведенное на тувинский язык в 1949 г. - роман А. С. Пушкина «Капитанская дочка»». Обложка и первый разворот издания. Фото предоставлено сотрудниками сектора книжных памятников Национальной библиотеки им А. С. Пушкина.

Photo 2. An edition of A. S. Pushkin's “The Captain's Daughter” translated into Tuvan in 1949. Photo courtesy of the Book Monuments Sector, A.S. Pushkin National Library of Tuva.

А. П. Чехова «Человек в футляре» (М. Хомушку), И. С. Тургенева «Певцы» (Ю. Кюнзегеш), Б. С. Житкова «Что бывало» (С. Шойгу), Н. В. Гоголя «Ревизор» (Ш. Сат), М. Горького «Детство» (С. Серен), М. Горького «В людях (О. Саган-оол) и «В Америке» (А. Делгер-оол), А. П. Гайдара «Школа» (А. Белек-Баир), М. Горького «Мои университеты» (Б. Ондар) и «Дед Архип и Ленька» (М. Монгуш), Л. Т. Космодемьянской «Повесть о Зое и Шуре» (К. Аракчаа), А. Фадеева «Молодая гвардия» (Ю. Аранчын, С. Сюрюн-оол, Б. Ондар, Д. Монгуш), Л. Н. Толстого «Казаки» (Б. Ондар), М. Шолохова «Судьба человека» (С. Пюрбю).

В 1960-е годы тувинскими переводчиками были переведены и изданы следующие произведения русской литературы: А. П. Чехова «Рассказы» (С. Сарыг-оол), Л. Н. Толстого «Хаджи Мурат» (С. Пюрбю), М. Шолохова «Поднятая целина» (О. Саган-оол, Б. Ондар, С. Пюрбю), Л. Н. Толстого «Детство Никиты» (С. Пюрбю), Э. Г. Казакевич «Синяя тетрадь» (Д. Куулар), М. Горького «Дело Артамонова» (С. Пюрбю), Н. В. Гоголя «Повести» (Б. Л. Ондар), Л. Н. Толстого «Холстомер» (Д. О. Кысыгбай).

В 1970-е годы тувинскими переводчиками была осуществлена работа по переводу произведений И. С. Тургенева «Накануне» (Е. Танова), Е. Ильиной «Четвертая высота» (К. К. Кудажы), С. Болдырева «Повесть о Георгии Димитрове» (К. Диича, С. Паву), М. Горького «Свидание» (В. Монгуш), А. С. Грибоедова «Горе от ума» (А. А. Даржай), А. Калинина «Эхо войны. Возврата нет» (В. Серен-оол), В. Липатова «Деревенский детектив» (А. Даржай), А. Толстого «Смерть Ивана Ильича» (Х. Ойдан-оол, М. Смирнова, К. Сат, С. Куулар), А. Калинина «Эхо войны» (К. К. Сат, В. С. Серен-оол), В. Астафьева «Пастух и пастушка» (А. Делгер-оол).

В 1980-е гг. переведены на тувинский язык произведения Б. Васильева «А зори здесь тихие» (О. К. Намчылак), В. Л. Василевской «Радуга» (М. Хенче-Кара, А. Дембирел, К. Сат, М. Хомушку), У. Федора 
«Человек среди людей» (С. Паву), А. С. Пушкина «Избранные произведения» (О. Саган-оол, Д. Монгуш, Ш. Сат, М. Хомушку).

В 1990-е и 2000-е годы наблюдается спад переводческой деятельности. Из переведенных с русского на тувинский язык произведений можно отметить сборник стихов и поэм С. Козловой в переводе А. Д. Даржаа; «Сказки народов мира» Г. Андерсена «Снежная королева» (Ш. Даржай), «Сказка о рыбаке и рыбке» А. С. Пушкина (А. Даржай); «Священная Библия» (Н. Куулар, М. А. Кужугет, Э. Б. Мижит).

\section{Принциипы разработки русско-тувинского параллельного корпуса тувинского языка}

При создании русско-тувинского параллельного подкорпуса на первом этапе был составлен список произведений русских писателей, переведенных на тувинский язык. Списки произведений были составлены из картотек Национальной библиотеки им. А. С. Пушкина, научно-библиографического отдела с сектором краеведения и редких изданий Тувинского государственного университета. В картотеке отдела краеведения Национальной библиотеки им. А. С. Пушкина имеется 380 наименований русско-тувинских переводных произведений, включающая переведенные с русского языка произведения зарубежных и советских писателей, из которых 203 отсканированы отделом оцифровки.

В отделе книжных памятников Национальной библиотеки им. А. С. Пушкина представлены первые переводные художественные произведения, в том числе, написанные на латинской графике в количестве 16 единиц.

На данный момент список русско-тувинской переводной литературы параллельного корпуса включает 110 наименований, в состав которого входят также произведения зарубежных и советских писателей. Это составляет около $15 \%$ от имеющихся в Национальной библиотеке им. А. С. Пушкина и библиотеке Тувинского госуниверситета переводных произведений.

Из данного списка были отобраны произведения русской литературы для первоочередного включения в русско-тувинский параллельный подкорпус и дальнейшего анализа системных изменений.

В состав русско-тувинского параллельного корпуса были включены следующие произведения:

Лермонтов М. Ю. «Герой нашего времени» (2006 г., 185 с.) - «Бистиң уениң маадыры» (перевод О. Саган-оола, 1950 г., 138 с.);

Шолохов М. А. «Поднятая целина» (1977 г., 557 с.) - «Аңдарган кур чер» (первый перевод

О. Саган-оола, 1950 г., 411 с., второй перевод - Б. Ондара и С. Пюрбю, 1963 г., 444 с.);

- Катаев В. П. «Я, сын трудового народа» (1987 г., 197 с.) - «Мен - ажылчын чоннуң оглу мен» (перевод С. Сарыг-оола, 1952 г., 130 с.);

· Чехов А. П. «Человек в футляре» (1977 г., 54 с.) - «Хапта кижи» (перевод М. Хомушку, 1953 г., 50 c.);

Фадеев А. «Молодая гвардия» (1987 г., 646 с.) - «Аныяк гвардия» (перевод Ю. Аранчына, С. Сюрюн-оола, Б. Ондара, Д. Монгуша, 1955 г., 405 с.);

Горький М. «Свидание» (1988 г., 367 с.) - «Болчаг» (перевод В. Монгуша, 1974 г., 236 с.);

· Васильев Б. «А зори здесь тихие» (1990 г., 141 с.) - «А даң хаяазы мында шыпшың» (перевод К. Намчылака, 1980 г., 140 с.);

• Ильина Е. «Четвертая высота» (1946 г., 200 с.) - «Дөрткү бедик» (перевод К. Кудажы, 1988 г., 328 c.).

На 2019 г. объем собранного русско-тувинского корпуса составляет 7631813 словоупотреблений. Работа по созданию русско-тувинского параллельного корпуса продолжается. На данный момент ${ }^{1}$ осуществляется паспортизация, перевод в электронный формат, выравнивание текстов, языковой анализ только указанных произведений.

${ }^{1}$ Данные на 1 декабря 2019 года. 


\section{Паспортизация}

Паспортизация включает сведения об авторе, о названии произведения, годе выпуска, жанре произведения, количестве страниц, переводчике, названии произведения на тувинском языке, годе выпуска перевода произведения, названии издательства.

Пример паспортизации представлен в таблице 1.

Таблица 1. Паспортизация параллельных текстов Table 1. Certification of parallel texts

\begin{tabular}{|c|c|c|c|c|c|c|c|c|c|}
\hline $\begin{array}{c}\text { Название } \\
\text { произве- } \\
\text { дения }\end{array}$ & Год & 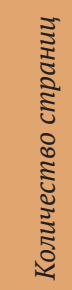 & Стиль & Жанр & $\begin{array}{c}\text { Название } \\
\text { произведения } \\
\text { на тувинском } \\
\text { языке }\end{array}$ & $\begin{array}{c}\text { ФИО } \\
\text { переводчика }\end{array}$ & $\begin{array}{c}\text { Год } \\
\text { изда- } \\
\text { ния }\end{array}$ & $\begin{array}{c}\text { Название } \\
\text { изда- } \\
\text { тельства }\end{array}$ & 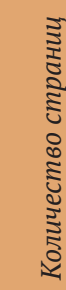 \\
\hline \multicolumn{10}{|c|}{ Николай Васильевич Гоголь } \\
\hline $\begin{array}{l}\text { Тарас } \\
\text { Бульба }\end{array}$ & 1948 & 154 & $\begin{array}{l}\text { Литера- } \\
\text { турно- } \\
\text { художес- } \\
\text { твенный }\end{array}$ & Повесть & Тарас Бульба & Ю. Кюнзегеш & 1952 & $\begin{array}{l}\text { Кызыл: Тув. } \\
\text { кн. изд-во }\end{array}$ & 147 \\
\hline \multicolumn{10}{|c|}{ Лермонтов Михаил Юрьевич } \\
\hline $\begin{array}{l}\text { Герой } \\
\text { нашего } \\
\text { времени }\end{array}$ & 1947 & 160 & $\begin{array}{l}\text { Литера- } \\
\text { турно- } \\
\text { художес- } \\
\text { твенный }\end{array}$ & Роман & $\begin{array}{l}\text { Бистиң уенин } \\
\text { маадыры }\end{array}$ & О. Саган-оол & 1950 & $\begin{array}{l}\text { Кызыл: Тув. } \\
\text { кн. изд-во }\end{array}$ & 138 \\
\hline
\end{tabular}

\section{Выравнивание текстов}

Из имеющихся на данный момент текстов в электронном виде составляется база параллельных текстов в формате Excel для дальнейшего анализа, обработки, создания разметки и программ поиска. Тексты выровнены на уровне предложений.

Пример базы представлен в таблице 2.

Таблица 2. Выравнивание русско-тувинских параллельных текстов

Table 2. Aligning parallel texts in Tuvan and Russian

\begin{tabular}{|c|c|c|c|c|c|c|c|}
\hline 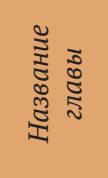 & 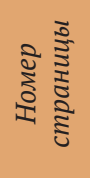 & 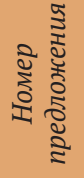 & $\begin{array}{c}\text { Предложение на русском } \\
\text { языке }\end{array}$ & $\begin{array}{l}\text { Эгениң } \\
\text { ады }\end{array}$ & $\begin{array}{c}\text { Арын } \\
\text { дугаары }\end{array}$ & $\begin{array}{c}\text { Домак } \\
\text { дугаары }\end{array}$ & $\begin{array}{c}\text { Перевод предложения } \\
\text { О. Саган-оола }\end{array}$ \\
\hline Глава I & 3 & 1 & $\begin{array}{l}\text { В конце января, } \\
\text { овеянные первой } \\
\text { оттепелью, хорошо } \\
\text { пахнут вишневые сады. }\end{array}$ & $\begin{array}{l}\text { Бирги } \\
\text { эге }\end{array}$ & 3 & 1 & $\begin{array}{l}\text { Январьниң төнчүзүнде, } \\
\text { баштайгы чылыгга алыскан } \\
\text { вишнялыг садтар кончуг-ла } \\
\text { эки чыталыр. }\end{array}$ \\
\hline Глава I & 3 & 2 & $\begin{array}{l}\text { В полдень где-нибудь } \\
\text { в затишке (если } \\
\text { пригревает солнце) } \\
\text { грустный, чуть внятный } \\
\text { запах вишневой коры } \\
\text { поднимается с пресной } \\
\text { сыростью талого снега, } \\
\text { с могучим и древним } \\
\text { духом проглянувшей } \\
\text { из-под снега, из-под } \\
\text { мертвой листвы земли. }\end{array}$ & $\begin{array}{l}\text { Бирги } \\
\text { эге }\end{array}$ & 3 & 2 & $\begin{array}{l}\text { Дал-дүьште кайы-бир ыжык } \\
\text { черге (бир эвес хүн дээп турар } \\
\text { болза) вишня картының уян, } \\
\text { дөңгүп билдинер чыды дээрге, } \\
\text { шылбыртың харның чаагай } \\
\text { шыгы-биле, хар адаандан, өлүг } \\
\text { бүрүлерниң адаандан бакылап } \\
\text { келген чыдар черниң күчүлүг } \\
\text { болгаш буруңгу чыды-биле } \\
\text { холужуп көдүрлүп турар. }\end{array}$ \\
\hline
\end{tabular}




\begin{tabular}{|c|c|c|c|c|c|c|c|}
\hline Глава I & 3 & 3 & $\begin{array}{l}\text { Тонкий многоцветный } \\
\text { аромат устойчиво } \\
\text { держится над садами } \\
\text { до голубых потемок, } \\
\text { до поры, пока не } \\
\text { просунется сквозь } \\
\text { голызины ветвей } \\
\text { крытый прозеленью рог } \\
\text { месяца, пока не кинут } \\
\text { на снег жирующие } \\
\text { зайцы опушенных } \\
\text { крапин следов... }\end{array}$ & $\begin{array}{l}\text { Бирги } \\
\text { эге }\end{array}$ & 3 & 3 & $\begin{array}{l}\text { Караңгы дүн дүшкүже, куу } \\
\text { ногаан-биле шыптынып } \\
\text { алган ай мыйысталы берген, } \\
\text { буъдуктарның ходургуларын } \\
\text { өтүр көстүп келгиже, одарлаан } \\
\text { койгуннар бөкпек истерин } \\
\text { харга баскыже чедир хөй-янзы } \\
\text { чаагай чыт садтар кырында } \\
\text { туруштуу-биле туттунуп } \\
\text { турар... }\end{array}$ \\
\hline
\end{tabular}

\section{Анализ параллельных текстов}

В исследованиях А. В. Байыр-оол, Е. В. Тюнтешевой (Байыр-оол, Тюнтешева, 2016), А. А. Озоновой, Е. В. Тюнтешевой (Озонова, Тюнтешева 2017), М. Д. Чертыковой, В. Я. Фета (Чертыкова, Фет, 2018), А. Н. Майзиной (Майзина, 2018), А. А. Озоновой, Е. В. Тюнтешевой, Н. Н. Фединой (Озонова, Тюнтешева, Федина, 2019) проведен анализ проблем перевода языковых средств в параллельных текстах на материале тюркских языков Южной Сибири.

Сравнительный анализ русско-тувинских параллельных текстов позволяет определить степень эквивалентности и неэквивалентности перевода; выявить трудности передачи лексики, содержащей национально-культурный компонент (слова-реалии); рассмотреть лексико-семантические и стилистические трансформации при переводе, способы перевода.

Для анализа были привлечены параллельные русско-тувинские тексты М. Шолохова «Поднятая целина», М. Ю. Лермонтова «Герой нашего времени», Б. Васильева «А зори здесь тихие», А. Фадеева «Молодая гвардия».

Данные произведения были отобраны по нескольким причинам.

Во-первых, по проблемно-тематическому принципу:

- общественная ситуация 30-40-х годов XIX века (М. Ю. Лермонтов «Герой нашего времени»);

- коллективизация сельского хозяйства (М. Шолохов «Поднятая целина»);

- события во время Великой Отечественной войны (Б. Васильев «А зори здесь тихие», А. Фадеев «Молодая гвардия»).

Во-вторых, по языковым особенностям. Так, язык романа М. Ю. Лермонтова «Герой нашего времени» классический; для языка романа М. А. Шолохова «Поднятая целина» характерно наличие диалектной лексики, отражающей особенности быта, культуры, хозяйственной деятельности донского казачества; слов, имеющих экспрессивно-стилистическую окраску; фразеологических оборотов, пословиц, жаргонов, просторечий, характеризующих речевой портрет героев романа, отношение к людям, событиям.

В-третьих, по объемам. Произведения М. Ю. Лермонтова «Герой нашего времени», Б. Васильева «А зори здесь тихие» небольшие по своему объему; романы М. Шолохова «Поднятая целина», А. Фадеева «Молодая гвардия» относительно большие.

Первоочередными задачами лингвистического анализа параллельных русско-тувинских текстов явились:

- выявление и анализ этнокультурных реалий, анализ способов перевода данных единиц на тувинский язык;

- анализ способов перевода слов разных тематических групп; эмоционально-оценочной лексики, формул речевого этикета.

В результате анализа выровненных параллельных текстов на материале романа М. Шолохова «Поднятая целина» и двух его тувинских переводов, осуществленных О. Саган-оолом, Б. Ондаром и С. Пюрбю, например, выявлены лексические единицы, обозначающие названия пищи. Пища является основным элементом материальной культуры народа, отражающим особенности хозяйственной деятельности, уклада жизни, географических условий проживания носителей языка. Лексические единицы были разделены на шесть тематических групп (наименования жидких овощных блюд; 
наименования жидких блюд из муки; наименования блюд из мяса; наименования крупяных блюд; наименования мучных блюд; наименования молочной пищи). Описаны проблемы перевода лексических единиц, обозначающих названия пищи.

Так, например, при переводе фразеологизма «хлеб-соль», являющегося символом гостеприимства русского народа, О. Саган-оол заменил словосочетанием аяк-шай (аяк - 'чаша', шай - 'чай'), так как у тувинцев признаком гостеприимства является чай - 'шай’ (Шараева, Айыжы, 2019). При переводе слов блины - ‘тонкая лепешка из кислого жидкого теста, испеченная на сковороде, на жару', оладыи - ‘толстая лепешка из пшеничной муки, изжаренная на сковороде’, не имеющих соответствий в тувинском языке, переводчики подобрали слово боова - 'пова, пресная лепешка, жаренная в масле', не совсем точно передающее значения лексем блины, оладьи. Слово вареники - 'род маленьких пирожков из пресного теста, начиненных творогом, ягодами, употр. в вареном виде’ Б. Ондаром, С. Пюрбю переведено лексемой хуужуур как «пирожок», что не совсем соответствует слову вареники. При переводе слов щи - 'жидкое кушанье, род супа из капусты или щавеля, шпината', борщ - 'суп со свеклой и другими овощами', не имеющих аналогов в тувинском языке, О. Саган-оол их заменил словом мүн - ‘бульон, суп’. Для лексемы сметана - 'молочный продукт из кислых сливок’ Б. Ондар, С. Пюрбю подобрали слово өреме - ‘сливки, пенки’ (с кипяченого молока) (Ондар, 2019: 383).

Языковой анализ перевода слов-реалий в главе «Бэла» романа М. Ю. Лермонтова «Герой нашего времени» в переводе О. Саган-оола показал, что слова-реалии переводятся, в основном, способом транслитерации. Но, помимо этого, используется также и способ перевода через вариантное соответствие (аналог). Данный способ использован при переводе слов:

чадра - ‘легкое покрывало, закрывающее голову и лицо женщины и спускающееся по плечам

вниз’ через тув. думаалай - ‘свадебное головное покрывало (у невесты)' и тув. бүдээлге - 'летний головной убор из сукна (для защиты от дождя)’;

· калым - 'обычай платить выкуп за невесту её родителям' через тув. суй-белек - 'свадебный (дорогой) подарок; дар; награда’;

· Коран - ‘священная книга мусульман’ через тув. шажын ному - ‘духовная книга';

• Аллах - ‘Бог, творец всего сущего в исламе’ через тув. Бурган - ‘бог; божество’.

В переводах некоторых слов не раскрывается полное лексическое значение данных слов (этнокультурных реалий)' ${ }^{1}$. Например, джигитовка - 'разнообразные сложные упражнения на скачущей лошади’ переведено через тув. аът чарыштырар - ‘конные скачки, состязание’; буза - 'хмельной напиток, изготовлявшийся из проса, гречихи, ячменя’ тув. арага - 'спиртосодержащий алкогольный напиток'.

\section{Заключение}

Создание параллельного русско-тувинского корпуса текстов проводится только в рамках проекта Госзадания НОЦ «Тюркология» Тувинского государственного университета. В этой работе задействован небольшой штат сотрудников Центра. Этим объясняется небольшой объем представленных параллельных русско-тувинских текстов. На данном этапе продолжается работа по пополнению корпуса русско-тувинской переводной литературы.

В создаваемом корпусе представлены большей частью художественные произведения, имеется небольшой массив текстов официально-деловых документов и поэтических текстов. Необходим сбалансированный по составу корпус. Техническая работа по переводу в цифровой формат, выравниванию и редактированию текстов занимает много времени и сил. Первые переводные произведения находятся в фондах редких книг библиотек, многие из них имеются в единственном экземпляре. Некоторые переводные тексты приходится переводить в цифровой формат вручную. Выравнивание имеющихся в цифровом формате параллельных текстов на сегодняшний день осуществляется в программе Exсеl вручную. Несмотря на существующие трудности, работа по созданию корпуса параллельных текстов продолжается. Корпус параллельных текстов существует на данный момент только в локальной версии. Идет работа по созданию автоматических программ поиска.

${ }^{1}$ Проблема русско-тувинских переводов терминов, например, растений проанализирована в работе М. В. Бавуу-Сюрюн, Н. Н. Широбоковой, А. М. Самдан (Бавуу-Сюрюн, Широбокова, Самдан, 2018). 
Осуществляется работа по анализу языковых особенностей перевода некоторых произведений корпуса (М. Шолохов «Поднятая целина», М. Ю. Лермонтов «Герой нашего времени», Н. Островский «Как закалялась сталь», А. Фадеев «Молодая гвардия», Б. Васильев «А зори здесь тихие»).

Продолжается работа над лингвистическим анализом параллельных русско-тувинских текстов:

- выявляются национально-культурные реалии, анализируются способы перевода реалий на тувинский язык;

- анализируются способы перевода слов разных тематических групп; эмоционально-оценочной лексики, формул речевого этикета.

Таким образом, в статье представлены первые предварительные итоги создания русско-тувинского параллельного корпуса в 2017-2019 гг. В дальнейшем предстоит большая работа по пополнению корпуса, выравниванию текстов, созданию программ поиска. На сегодняшний день в корпусе представлены в основном художественные произведения и тексты официально-деловых документов. Необходимо пополнение корпуса текстами разных жанров и стилей. По плану проектной части Государственного задания Министерства образования и науки РФ проанализированы системные изменения в лексике на примере параллельных текстов.

\section{Благодарности}

Авторы выражают благодарность директору научной библиотеки Тувинского государственного университета Ирине Витальевне Подик, заведующему отделом национальной и краеведческой литературы Национальной библиотеки им. А. С. Пушкина РТ Елене Михайловне Ак-Кыс, заведующему сектором книжных памятников Национальной библиотеки им. А. С. Пушкина РТ Сайзане Викторовне Сат за предоставленную информацию.

\section{СПИСОК ЛИТЕРАТУРЫ}

Андреева, Е. Г. (2006) Анализ переводческих соответствий на материале параллельного корпуса текстов // Компьютерная лингвистика и интеллектуальные технологии. Труды международной конференции «Диалог 2006» / отв. ред. Н. И. Лауфер, А. С. Нариньяни, В. П. Селегея. М. : РГГУ. С. 26-30. 644 с.

Бавуу-Сюрюн, М. В. (2006) Вопросы создания электронных ресурсов тувинского языка: некоторые итоги, неотложные задачи и перспективы [Электронный ресурс] // Новые исследования Тувы. № 4. URL: https://nit.tuva.asia/nit/article/view/610 (дата обращения: 09.11.2019).

Бавуу-Сюрюн, М. В., Широбокова, Н. Н., Самдан, А. М. (2018) Названия лекарственных растений Тувы в словарях [Электронный ресурс] // Новые исследования Тувы. № 4. URL: https://nit.tuva.asia/nit/ article/view/805 (дата обращения: 10.12.2019). DOI: https://doi.org/10.25178/nit.2018.4.2

Байыр-оол, А. В., Озонова, А. А. (2016) Переводы русской литературы на алтайский и тувинский языки (конец XIX - начало XXI в.) // Книга: Сибирь - Евразия. Труды I Международного конгресса ГПНТБ СО РАН / отв. ред. И. В. Лизунова / в 3 т. Новосибирск : Государственная публичная научнотехническая библиотека Сибирского отделения Российской академии наук Т. 2. 398 с. С. 239-246.

Байыр-оол, А. В., Тюнтешева, Е. В. (2016) Лексические средства, использованные в алтайском и тувинском переводах романа М. А. Шолохова «Поднятая целина» // Языки и фольклор коренных народов Сибири. № 1 (30). Новосибирск : Федеральное государственное бюджетное учреждение науки Институт филологии Сибирского отделения Российской академии наук. 128 с. С. 76-83.

Добровольский, Д. О. (2009) Корпус параллельных текстов в исследовании культурно-специфичной лексики // Национальный корпус русского языка: 2006-2008. Новые результаты и перспективы / отв. ред. В. А. Плунгян. СПб. : Нестор-История. 502 с. С. 383-401.

Добровольский, Д. О., Кретов, А. А., Шаров, С. А. (2005) Корпус параллельных текстов: архитектура и возможности использования // Национальный корпус русского языка. Результаты и перспективы / отв. ред. В. А. Плунгян. М. : Индрик. 344 с. С. 263-296.

Донгак, У. А. (2018) Особенности первых переводных произведений тувинской литературы // Филологические науки. Вопросы теории и практики. № 7 (85). Ч. 1. С. 29-33.

Калзан, А. К., Куулар, Д. С. (1956) О художественных переводах с русского на тувинский язык // Ученые записки. Вып. IV. Кызыл: Тувинское книжное издательство. С. 118-142. 
Майзина, А. Н. (2018) О двух переводах «Сказки о военной тайне, Мальчише-Кибальчише и его твёрдом слове» А. Гайдара на алтайский язык // Материалы Всероссийской научно- практической конференции, посвященной творчеству известного алтайского писателя и переводчика Паслея Самыка / отв. ред. М. С. Дедина. Горно-Алтайск: Бюджетное научное учреждение Республики Алтай «Научно-исследовательский институт алтаистики им. С. С. Суразакова». 376 с. С. 198-210.

Озонова, А. А., Тюнтешева, Е. В. (2017) Лексические и грамматические особенности алтайских переводов повести А. П. Чехова «Палата № 6» // Вестник Новосибирского государственного университета. Серия: История, филология. Т. 16. № 9. С. 121-136.

Озонова, А. А., Тюнтешева, Е. В., Федина, Н. Н. (2019) Языковые особенности перевода текста «Евангелия от Матфея» 1910 г. на алтайский язык // Северо-Восточный гуманитарный вестник. № 1 (26). C. 85-92. DOI: 10.25693/SVGV.2019.01.26.011

Ондар, В. С. (2019) Особенности перевода названий пищи с русского языка на тувинский язык (на материале оригинала и перевода романа М. А. Шолохова «Поднятая целина») // Филологические науки. Вопросы теории и практики. Том. 12. Вып. 9. С. 379-383.

Салчак, А. Я., Байыр-оол, А. В. (2013) Электронный корпус тувинского языка: состояние, проблемы // Мир науки, культуры, образования. № 6 (43). С. 408-409.

Салчак, А. Я., Ондар, В. С., Кужугет, Ш. Ю. (2018) Создание электронных корпусов тувинского языка // Евдокия Иннокентьевна Коркина: биографика и интерпретация научного и творческого наследия: сборник научных статей / отв. ред. Н. И. Данилова., Н. И. Попова., Е. М. Самсонова. Якутск: Институт гуманитарных исследований и проблем малочисленных народов Севера Сибирского отделения РАН. 282 с. C. $130-133$.

Хертек, А. Б., Ооржак, Б. Ч. (2012) О морфологической разметке электронного корпуса текстов тувинского языка // Филологические науки. Вопросы теории и практики. № 7 (18). Ч. II. С. $214-218$.

Чертыкова, М. Д., Фет, В. Я. (2018) «Приключения Алисы в стране чудес» Л. Кэрролла на хакасском языке: лексико-семантические особенности перевода // Родной язык: лингвистический журнал. № 1 (8). С. 85-108.

Шараева Т. И., Айыжы Е. В. (2019) Чай в традиционной культуре калмыков и тувинцев [Электронный ресурс]// Новые исследования Тувы. № 4. URL: https://nit.tuva.asia/nit/article/view/890 (дата обращения: 10.12.2019). DOI: 10.25178/nit.2019.4.12

Tyers, F., Bayyr-ool, A., Salchak, A., Washington, J. (2016) A finite-state morphological analyser for Tuvan // Proceedings of the Tenth conference on International Language Resources and Evaluation (LREC'16) Editors: N. Calzolari (Conference Chair) et al. Portorož: European Language Resources Association. 4693 p. P. 2562-2567.

Washington, J. N., Bayyrool, A., Salchak, A., Tyers, F. M. (2016) Development of a finite-state model for morphological processing of Tuvan // Родной язык: лингвистический журнал. № 1 (4). C. $156-187$.

Дата поступления: 11.12.2019 г.

\section{REFERENCES}

Andreeva, E. G. (2006) Analiz perevodcheskikh sootvetstvii na materiale parallel'nogo korpusa tekstov [Analysis of translation correspondences: the case of a parallel corpus of texts]. In: Komp'yuternaya lingvistika $i$ intellektual'nye tekhnologii [Computational linguistics and intellectual technologies]. Proceedings of the international conference "Dialog 2006"] / ed. by N. I. Laufer, A. S. Narignani and V. P. Selegei. Moscow, RGGU. 644 p. Pp. 26-30. (In Russ.).

Bavuu-Surun, M. V. (2006) Voprosy sozdaniya ehlektronnykh resursov tuvinskogo yazyka: nekotorye itogi, neotlozhnye zadachi i perspektivy [Issues of creating electronic resources of the Tuvan language: some results, urgent tasks and prospects]. The New Research of Tuva, no. 4. URL: https://nit.tuva.asia/nit/article/view/610 (access date: 09.11.2019). (In Russ.).

Bavuu-Surun, M. V., Shirobokova, N. N. and Samdan A. M. (2018) The Nomenclature of Medicinal Plants of Tuva in Dictionaries. The New Research of Tuva, no. 4 [on-line] Available at: https://nit.tuva.asia/nit/article/ view/805 (accessed: 10.12.2019). (In Russ.). DOI: https://doi.org/10.25178/nit.2018.4.2

Bajyr-ool, A. V. and Ozonova, A. A. (2016) Perevody russkoi literatury na altajskii i tuvinskii yazyki (konets XIX - nachalo XXI v.) [Translations of Russian literature into Altai and Tuvan languages (late $19^{\text {th }}-$ early 21st centuries)]. In: Kniga: Sibir' - Evraziya [Book: Siberia - Eurasia]. Proceedings of the $1^{\text {st }}$ International 
Congress of SPSL SB RAS / ed. by V. Lizunova. In 4 vol. Novosibirsk, Gosudarstvennaya publichnaya nauchnotekhnicheskaya biblioteka Sibirskogo otdeleniya Rossiiskoi akademii nauk. Vol. 2. 398 p. Pp. 239-246. (In Russ.).

Bajyr-ool, A. V. and Tyuntesheva E. V. (2016) Leksicheskie sredstva, ispol'zovannye v altaiskom i tuvinskom perevodakh romana M. A. Sholokhova «Podnyataya tselina» [Lexical means used in Altai and Tuvan translations of the novel "Virgin Soil Upturned" by M. A. Sholokhov]. In: Yazyki i fol'klor korennyh narodov Sibiri [Languages and folklore of the indigenous peoples of Siberia], no. 1 (30). Novosibirsk, Federal'noe gosudarstvennoe biudzhetnoe uchrezhdenie nauki Institut filologii Sibirskogo otdeleniia Rossiiskoi akademii nauk. 128 p. Pp. 76-83. (In Russ.).

Dobrovol'skii, D. O. (2009) Korpus parallel'nykh tekstov v issledovanii kul'turno-spetsifichnoi leksiki [A corpus of parallel texts in the study of culturally specific vocabulary]. In: Natsional'nyi korpus russkogo yazyka: 2006-2008. Novye rezul'taty i perspektivy [National Corpus of the Russian Language: 2006-2008. Results and Prospects] / ed. by. V. A. Plungyan. St. Petersburg, Nestor-Istoriya. 502 p. Pp. 383-401. (In Russ.).

Dobrovol'skii, D. O., Kretov, A. A. and Sharov, S. A. (2005) Korpus parallel'nykh tekstov: arkhitektura i vozmozhnosti ispol'zovaniya [A Corpus of Parallel Texts: Architecture and Usability]. In: Natsional'nyi korpus russkogo yazyka. Rezul'taty i perspektivy [National corps of the Russian language. Results and Prospects] / ed. by V. A. Plungyan. Moscow, Indrik. 344 p. Pp. 263-296. (In Russ.).

Dongak, U. A. (2018) Osobennosti pervykh perevodnykh proizvedenii tuvinskoi literatury [Features of the first translated works in Tuvan literature]. Philological Sciences. Issues of Theory and Practice, no. 7 (85), part 1, Pp. 29-33. (In Russ.). DOI: 10.30853/filnauki.2018-7-1.6

Kalzan, A. K. and Kuular, D. S. (1956) O khudozhestvennykh perevodakh s russkogo na tuvinskii yazyk [On the literary translations from Russian into Tuvan]. In: Uchenye zapiski. Vol. IV. Kyzyl, Tuvan book publishing house. Pp. 118-142. (In Russ.).

Mayzina, A. N. (2018) O dvukh perevodakh «Skazki o voennoi taine, Mal'chishe-Kibal'chishe i ego tverdom slove» A. Gaidara na altaiskii iazyk [On two translations of «A tale of a war secret, Malchish-Kibalchish and his word of honour» by A. Gaidar into Altai language]. In: Materialy Vserossiiskoi nauchno- prakticheskoi konferentsii, posviashchennoi tvorchestvu izvestnogo altaiskogo pisatelia i perevodchika Pasleia Samyka [Materials of the AllRussian Scientific and Practical Conference dedicated to the work of the famous Altai writer and translator Pasley Samyk] / ed. by. M. S. Dedina. Gorno-Altaysk, Budget Scientific Institution of the Republic of Altai «Research Institute named after S. S. Surazakova». 376 p. Pp. 198-210. (In Russ.).

Ozonova, A. A. and Tyuntesheva, E. V. (2017) Leksicheskie i grammaticheskie osobennosti altaiskikh perevodov povesti A. P. Chekhova «Palata № 6» [Lexical and grammatical features of Altai translations of A. P. Chekhov's «Ward No. 6»]. Vestnik Novosibirskogo Gosudarstvennogo Universiteta. Series: History and Philology, vol. 16, no. 9, pp. 121-136. (In Russ.).

Ozonova,A.A., Tyntesheva, E. V. and Fedina, N. N.(2019) Iazykovye osobennosti perevoda teksta «Evangeliia ot Matfeia» 1910 g. na altaiskii iazyk [Language features of the translation of the text of the Gospel of St. Matthew into the Altai language (1910)]. North-Eastern Journal of Humanities, no. 1 (26), pp. 85-92. (In Russ.). DOI: 10.25693/SVGV.2019.01.26.011

Ondar, V. S. (2019) Osobennosti perevoda nazvanii pishchi s russkogo yazyka na tuvinskii yazyk (na materiale originala i perevoda romana M. A. Sholokhova «Podnyataya tselina») [Translation of food-related vocabulary from Russian into Tuvan (based on the original and translation of the novel «Virgin Soil Upturned» by M. A. Sholokhov). Filologicheskie nauki: Voprosy teorii i praktiki, no. 7 (85), vol. 12, issue 9, pp. 379-383. (In Russ.).

Salchak, A. Ya. and Bajyr-ool, A. V. (2013) Elektronnyi korpus tuvinskogo yazyka: sostoyanie, problemy [The electronic corpus of the Tuvan language: its current state and problems]. Mir nauki, kul'tury, obrazovaniia, no. 6 (43), pp. 408-409. (In Russ.).

Salchak, A. Ya., Ondar, V. S. and Kuzhuget, Sh. Yu. (2018) Sozdanie ehlektronnykh korpusov tuvinskogo yazyka [Setting up electronic corpora of the Tuvan language]. In: Evdokiya Innokent'evna Korkina: biografika i interpretatsiya nauchnogo i tvorcheskogo naslediya: sbornik nauchnykh statei [Evdokia Innokentyevna Korkina: biography and interpretation of research and creative heritage: a collection of articles] / ed. by N. I. Danilova, N. I. Popova, and E. M. Samsonova. Yakutsk, Institut gumanitarnykh issledovanii i problem malochislennykh narodov Severa Sibirskogo otdeleniya RAN. 282 p. Pp. 130-133. (In Russ.). 
Hertek, A. B. and Oorzhak, B. Ch. (2012) O morfologicheskoi razmetke elektronnogo korpusa tekstov tuvinskogo yazyka [On Tuvan language texts electronic corpus morphological marking]. Philological Sciences. Issues of Theory and Practice, no. 7 (18), part II, pp. 214-218. (In Russ.).

Chertykova, M. D. and Fet, V. Ya. (2018) Prikliucheniia Alisy v strane chudes» L. Kerrolla na khakasskom iazyke: leksiko-semanticheskie osobennosti perevoda [Alice's Adventures in Wonderland in Khakas: Lexicosemantic features of the translation]. Rodnoy Yazyk, no. 1 (8), pp. 85-108. (In Russ.).

Sharaeva T. I. and Aiyzhy E. V. (2019) Tea in the traditional culture of the Kalmyks and Tuvans. The New Research of Tuva, no. 4 [online] Available at: https://nit.tuva.asia/nit/article/view/890 (access date: 10.12.2019). (In Russ.) DOI: 10.25178/nit.2019.4.12

Tyers, F., Bayyr-ool, A., Salchak, A. and Washington, J. (2016) A finite-state morphological analyser for Tuvan. In: Proceedings of the Tenth conference on International Language Resources and Evaluation (LREC'16). Editors: N. Calzolari (Conference Chair) et al. Portorož, European Language Resources Association. 4693 p. Pp. 2562-2567.

Tyers, F., Bayyr-ool, A., Salchak, A. and Washington, J. (2016) Development of a finite-state model for morphological processing of Tuvan. Rodnoy Yazyk, no. 1 (4), pp. 156-187.

Submission date: 11.12.2019 2. 